\title{
TOURIST INITIATIVES AND EXTREME WILDERNESS IN THE NAKANAI MOUNTAINS OF NEW BRITAIN
}

[Received January 16th 2017; accepted February 13th 2017 - DOI: 10.21463/shima.11.1.11]

\author{
Jennifer Gabriel
}

The Cairns Institute, James Cook University <jennifer.gabriel@jcu.edu.au>

\section{Colin Filer}

The Australian National University <colin.filer@anu.edu.au>

\author{
Michael Wood \\ James Cook University <michael.wood@jcu.ed.au> \\ Simon Foale \\ James Cook University <simon.foale@jcu.edu.au>
}

\begin{abstract}
In 2013, the Government of Papua New Guinea identified East New Britain as the country's tourism centre. Tourism operators in the provincial capital welcomed the government's plan, but warned that poor infrastructure and the country's bad image overseas could prevent it from reaping the benefits of 'huge' tourism potential. Landowners in the Tentative World Heritage area of the Nakanai Mountains are keen to tap into the perceived potential of tourism development and are creatively monetising their rugged environment in the hope of attracting tourists for adventure tourism. The development of adventure tourism initiatives tap into notions of wild and rugged landscapes, combined with Western fantasies involving travel to dangerous places (mountains, jungles, caves, cascading rivers). We argue that, unless local communities are able to effectively exercise power and control over tourism ventures, the desire to proclaim ecotourism as the ideal alternative form of development risks subsuming local communities and their livelihoods into a future defined primarily by outsiders.
\end{abstract}

KEYWORDS: Tourism, wilderness, landscape, Nakanai Mountains, Papua New Guinea

Introduction

You have most likely never heard of the island of New Britain. Despite its familiar-sounding name, it's nowhere near its namesake - the island sits off the east side of Papua New Guinea, of which it is a province... It is a relatively large island at 15,724 sq km, and surely one of the least explored places in the world. It's the perfect place to undertake an adventure... (Red Bull, 2015: online)

Shima <www.shimajournal.org> ISSN: 1834-6057 
The island of New Britain in Papua New Guinea (PNG) is divided between two provinces - West New Britain (WNB) and East New Britain (ENB). Politically, each province is then divided into districts (two in WNB, four in ENB), which are further divided into local-level government (LLG) areas (between three and five in each district). There are very uneven levels of 'development' across the island, mainly because of variations in the level of household income from cash cropping (Hanson et al., 2001). As in other parts of the AsiaPacific region (Cramb and Curry, 2012), the palm oil industry has become a major driver of change in landscapes and livelihoods, and its expansion is partly responsible for historically high rates of deforestation on the island of New Britain (Buchanan et al., 2008). Furthermore, in recent decades, the lowland rainforests of New Britain have been subject to more intensive 'selective' logging than any comparable forest area in the rest of PNG (Filer, 1997), which means that 'pristine' native forests are now largely confined to the mountain slopes that are too steep for conventional logging equipment (Lindemalm and Rogers, 2001).

While oil palm and log exports are the main source of income for many rural communities, especially in WNB, the production of other agricultural commodities, especially cocoa, has made the more densely populated parts of the Gazelle Peninsula (the north-eastern half of ENB) one of PNG's most highly 'developed' regions (Epstein, 1968; Martin, 2013; Salisbury, 1969), well before the recent spread of oil palm estates into the province. As part of this more recent trend, the Pomio District of ENB has seen the alienation of large swathes of customary land through the grant of 'special agricultural and business leases' for industrial oil palm development (Gabriel et al., in press; Global Witness, 2014; Nelson et al., 2014). Notwithstanding the varying presence of 'development' throughout New Britain, villagers have been critical of modern-day institutions "for having failed to produce decisive fundamental change" (Lattas, 2010: xix).

At approximately 600 kilometres in length, and 80 kilometres at its widest, the reef-bound, crescent-shaped landmass of New Britain is the largest island in the Bismarck Archipelago. With a maximum elevation of 2440 metres above sea level, it is also the highest island. New Britain was largely formed by volcanic processes, and the active volcanoes on the island include Ulawun (the highest volcano in PNG), Langila, the Garbuna group, the Sulu Range, and Tavurvur and Vulcan near Rabaul, the former capital of ENB. New Britain's coastal plains give way to a rugged central mountain spine, composed of the (largely unlogged) Whiteman, Nakanai and Baining mountain ranges. These upland areas are described as "exceptionally rugged, with spectacular karst terrain including the internationally acclaimed Nakanai megadolines" (Aplin and Opiang, 2011: 85). The Nakanai Range constitutes part of the border between the two provinces, but most of the range is located in ENB and is a very long way from the densely populated and highly developed area around the old and new provincial capitals, Rabaul and Kokopo (see Figure 1), which have a very different appeal for tourists.

Tourism regions have spatial differences that can determine how the destination develops (Gartner, 2004; Nepal, 2007; Saarinen, 2004), however their specific identities are frequently shaped by hegemonic discourses that construct how the destination is represented (Saarinen, 2004: 161). Local communities are not passive recipients, and are often involved in efforts to attract more tourists (Duncanson, 2002). At the same time, tourism involves a social process of change in which human systems, values and communities are being integrated into global social and economic networks (Robertson, 1992; Wang, 2000; Wood, 2000).

Shima Volume 11 Number 12017

$-123-$ 


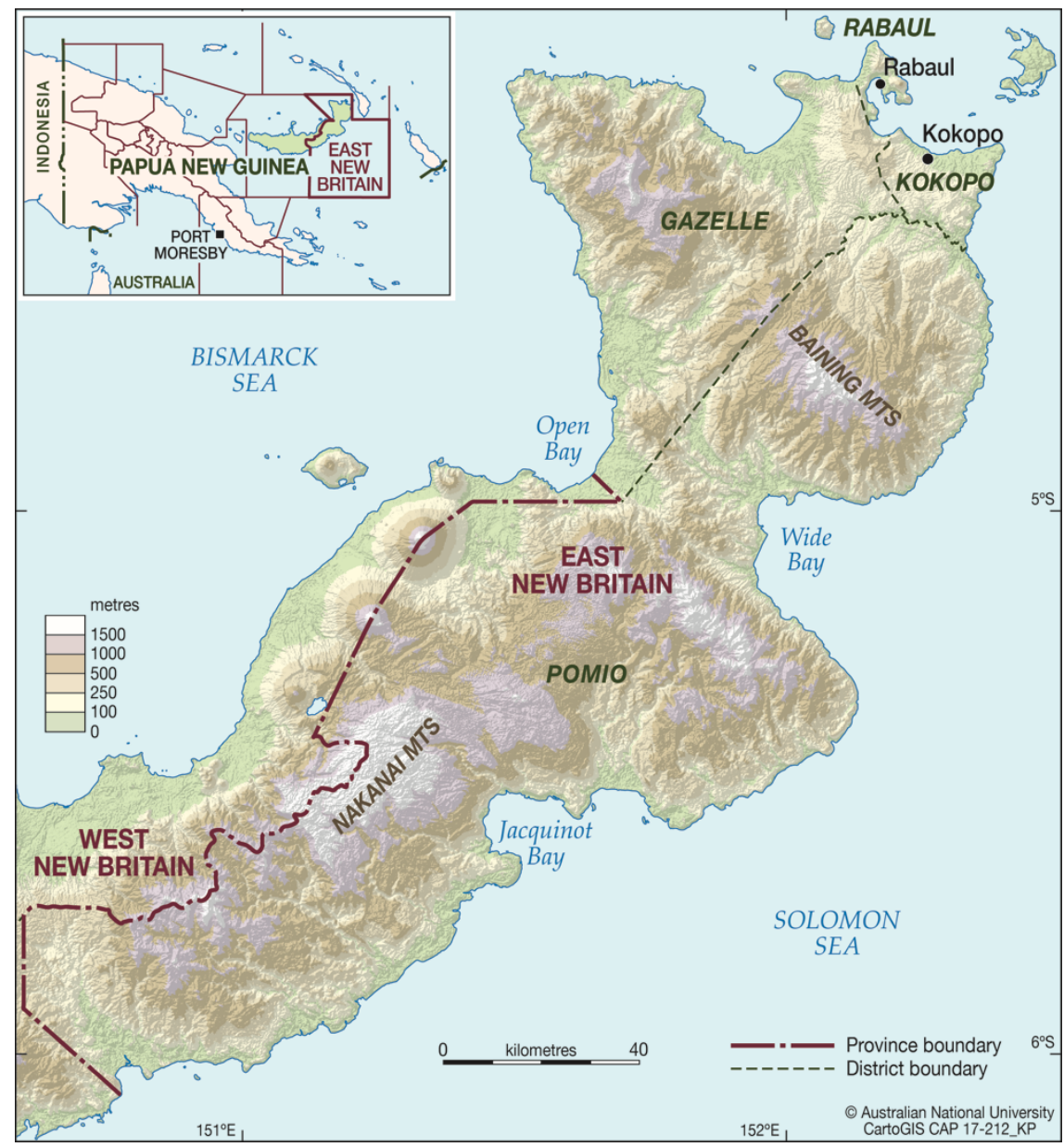

Figure 1 - Map of East New Britain Province (source Australian National University, reproduced with permission)

In the highly competitive global tourism industry, the myth of tropical islands as paradises to be conquered and/or consumed generates an endless demand for new kinds of 'lands', different from the others. Ecotourism or 'green travel' - the fastest growing tourism sector globally - has been hailed as a mechanism to protect ecosystems, empower rural communities and provide a host of other benefits (Honey, 1999; International Ecotourism Society, nd). However, close examination shows a much more complex reality (Honey, 2008). Researchers urge caution about the potential negative impacts of tourism on cultural heritage (Russo, 2006; Shackley, 1998), which include cultural commodification and compromised authenticity (McGavin, 2007). In the context of world heritage, Wilson and colleagues (2012) argue that tourism initiatives can be a vital component of community-led conservation and an important opportunity for cultural transmission and revival. An emerging body of literature highlights how local actors are attempting to take control of tourist access to their communities (Coronado, 2014; Nielsen and Wilson, 2012). Recent empirical research in Milne Bay Province, PNG indicates that the presence of strong community agency played a significant factor in the early success of 'bottom up' 
tourism initiatives. Low numbers of visitors enabled the community "to undertake development at its own pace, giving it the ability to exercise control over the pace of social changes, and to monitor any undesired impacts" (Sakata and Prideaux, 2013: 896).

Examining the intersection of geography, history, and 'representations of place' shaping tourism marketing in ENB, our case study considers the conceptual nature of tourist destinations in two very different landscapes. ${ }^{1}$ While the mass-tourism market in the provincial capital (Kokopo) is driven by national economic priorities, we argue that tourism initiatives in the remote Nakanai Range region are simultaneously a reflection of Western desires for transcendental experiences, as well as the product of local desires to secure a future of their own creation. This imagined future, however, is largely influenced by the Western quest for the sacred and the 'natural', and relies upon the illusion of local or indigenous people as natural stewards of the environment.

\section{The Rabaul-Kokopo corridor}

On the island of New Britain, the volcanic activity that has irrevocably altered the landscape is now a defining part of the region's future. As a tourist destination, the region's volcanoes and their tectonic plates create the possibility of extreme natural environments and future events. For example:

The Rabaul volcano is of a type that is potentially very dangerous: a collapse caldera. This type of volcano is prone to violent large-scale eruptions. During such major eruptions, the rapid evacuation of a central magma chamber may cause the centre of the volcano to collapse and may send clouds of hot ash across the land surface in all directions. The result can be the development of a central depression or caldera. The last such violent eruption was in about 6 oo AD. In this eruption, clouds of hot gas and rock particles spilled across the neighbouring countryside to distances of up to $50 \mathrm{~km}$ from the volcano. The caldera that formed is what we now know as Rabaul Harbour. (Davies, 1995: 4)

In 1937 Mt Tavurvur erupted and almost entirely destroyed Rabaul, which was then the administrative capital of the Territory of New Guinea. Almost two decades later, in 1954, an observer wrote: "Although Rabaul itself is attractive, and is surrounded by many districts of beauty and interest, no attempt had yet been made to develop the profitable tourist business" (Robson, 1954, cited in Tateyama, 2006: 214). Between 1954 and 1994, concerted attempts were made to turn Rabaul into a popular tourist destination. Air services increased during the 1960s, with Trans Australia Airlines and Ansett Airlines introducing Boeing 727 jet aircraft into their fleets. Passengers could leave Rabaul in the morning and reach any state capital in Australia the same day (Threlfall, 2012: 437). Cruise ships began to arrive, and the Reverend Neville Threlfall recalls that "residents became used to the sight of elderly gentlemen laden with cameras and purple-haired matrons in floppy sun-hats streaming offshore from air-conditioned liners and gasping in the steamy heat" (ibid: 438).

${ }^{1}$ The research is part of an Australian Research Council Linkage Project involving James Cook University, the Australian National University, Extent Heritage (Archaeological Consultants and Heritage Advisors) and Partners with Melanesians NGO.

Shima Volume 11 Number 12017

$-125-$ 
In 1994, when three volcanoes - Tavurvur, Vulcan and Rabalankaia - erupted, stately colonial buildings and tree-lined avenues were destroyed as tonnes of ash fell on the town formerly known as 'the jewel of the Pacific' (Tateyama, 2006). The rain of ash caused $80 \%$ of the buildings to collapse, while 105,00o displaced people received food and shelter in care centres after the first weeks of the eruption, and local communities were obliged to adopt all manner of adaptive responses (Neumann, 1996). With Rabaul buried deep under ash, Kokopo, some 20 kilometres away, was made the administrative capital of ENB. Rabaul today is simultaneously a symbol of the region's historical misfortune and an icon of redemption:

Located on Papua New Guinea's northeastern tip, this province - blessed with natural beauty but plagued with an unlucky past - has literally risen from the ashes. The former capital of New Britain is a town with a colourful history and no stranger to rebuilding itself from the ground up. It's been destroyed by volcano eruptions in 1937 and 1994, as well as being all but flattened by aerial bombardment in World War II.... Since 1994, Rabaul has returned to life and its harbour is still one of the most impressive in the entire Pacific basin. (P\&O Destinations, nd: online)

Catastrophic violent eruptions can have disastrous consequences for the local economy and subsistence livelihoods, but may also generate unexpected opportunities. Tourism is now a major industry in Rabaul. In articulating a unique brand, the PNG Tourism Promotion Authority (TPA) targets the province's historical misfortune and the ominous potential of active volcanoes. War tourism supplements the disaster narrative of volcanic tourism: "East New Britain has a fascinating World War 2 history and visitors can explore Japanese cave systems, barge tunnels, aircraft wrecks and submarines" (PNGTPA, n.d.). Combined with fishing, water activities (swimming, snorkelling and diving on WWII sites), the mythology of unspoilt tropical islands (Jędrusik, 2004: 280) and grumbling volcanoes establishes a distinct tourism brand that lures tourists to the shores of ENB. Operating within close proximity to key regional markets, the organised mass tourism industry in Rabaul and Kokopo now involves a complex network of tour operators and tour guides.

In 2013, the national government declared ENB to be the tourism hub of PNG. ${ }^{2}$ As a way to route visitors away from the national capital, Port Moresby, with its negative high-risk international reputation for social instability and crime, the TPA orientated its efforts towards increasing cruise liner tourism (Mayring, 2015). With the regional economy highly dependent on the needs of modern tourists and the tourist trade, tourism and its development is now a highly political and socio-cultural issue in this province.

In 2015, 15 cruise liners visited ENB, and another 16 were due to arrive in the course of 2016, each carrying around 1000 tourists (Unattributed, 2016a). In 2017, industry sources anticipate that 23 cruise liners will visit the province. ${ }^{3}$ The TPA's focus in the next 5-10 years will be turning Rabaul into a more accessible cruise tourism destination (Mayring, 2015). Globally, the cruise ship market is massive and is experiencing exponential growth.

${ }^{2}$ PNG's tourism industry was expected to expand by $6.7 \%$ in 2016 , with annual growth averaging $5.3 \%$ through to 2025, according to the World Travel and Tourism Council, placing it in the top $10 \%$ of the 184 countries surveyed in terms of forecast growth (Oxford Business Group, 2015).

${ }^{3}$ See http://www.cleancruising.com.au/port.asp?port=PGRAB

Shima Volume 11 Number 12017

- 126 - 
More than 400 ships sail annually, with around 23 million passengers. By 2020, 55 new ships will enter the industry and many of those ships will be deployed in the Asia-Pacific region. Tourists' needs and values will therefore have greater influence in shaping 'representations of place', which includes the stereotypical production of cultural activities.

The space of otherness in Rabaul is constructed through cultural performances, the visibility of war relics, and the ashen ruins of a once-thriving town. Prudently planned, delimited and mapped into zones inscribed by rationalising processes, tourism initiatives in this region are a metaphor for national development, in both its material and ideological sense.

Fire dancers at the far edges of the global

At the time of the last national census in 2011, ENB had a population of roughly 330,000, two thirds of whom were concentrated in the far northeastern corner of the province, in an area that barely accounts for $10 \%$ of the provincial land mass. The Tolai people are the dominant ethnic group in this area, which includes the whole of Kokopo and Rabaul districts and the more accessible parts of Gazelle District (see map). It is generally thought that the ancestors of this Tolai population migrated to the Gazelle Peninsula from New Ireland in the late eighteenth century (Allen 2015). ${ }^{4}$ The subsequent growth of the Tolai population in this fertile volcanic environment involved a partial displacement of the original inhabitants, whose descendants are now generally known as 'Baining' people. Their name is associated with the Baining mountain range, since they occupy the less accessible parts of Gazelle District and the northeastern extremity of Pomio District (Filer and Lowe, 2011; Rohatynskyj, 2001; Whitehouse, 1990). The remaining part of Pomio District, including the Nakanai mountain range, which accounts for well over half of the provincial land mass, is occupied by a number of other ethnic groups speaking several distinct languages that are unrelated to those spoken by the Baining people (Panoff, 1969; Rew, 1993; Rohatynskyj, 2001).

As far as cultural tourism is concerned, the most famous tourist attraction that ENB is known for is the spectacular 'fire dance'. Every July, the Baining fire dancers become the main attraction of the annual National Mask Festival, which was introduced in 1995 to promote the 'mask cultures' of PNG. The festival takes place along the shores of Kokopo, the new provincial capital. Initiated men dance barefoot on fire, adorned with masks that supposedly represent the spirits of their ancestors. Originally an initiation and fertility rite, the fire dance has become commercialised to such an extent that tourists can make advance bookings for its performance at hotels and clubs. In 2004, the Baining received around 80o-100o kina (about 300 US dollars) for each performance (Tateyama, 2006: 220). The National Mask Festival is marketed as a 'must do' for the traveller who wants to experience something totally unique in the world (PNGTA, n.d.). In 2004, the fire dance was filmed by an American television crew for the Discovery Channel, and more recently, it was spectacularly exoticised in the 2014 documentary, Deepsea Challenge $3 D$.

${ }^{4}$ This migration is associated in Tolai oral histories with a volcanic eruption of what is now the Rabaul Caldera. Such eruptions, which occurred in 1761 and 1791, may have left parts of the Gazelle Peninsula largely unoccupied (Allen, 2015:304).

Shima Volume 11 Number 12017 
In his 2012 Deepsea Challenge expedition, film-maker and National Geographic 'Explorer in Residence', James Cameron, descended in a purpose-built undersea vehicle in the deep waters off Jacquinot Bay in Pomio District (see map), before heading off to the Mariana Trench in the Pacific Ocean. The eponymous documentary also features the ash-covered remains of Rabaul, as well as the fire dance. Anthropologist Jane Fajans, who previously conducted fieldwork with the Baining people (see Fajans, 1997), was invited to join Cameron's expedition to share her insights into the culture of the Baining people. She describes the transcendental qualities associated with the performance of the fire dance:

The masks are said to be representatives of bush spirits that live in the forest. The Baining say that people who walk around in the forest alone may meet these spirits, and then they come back to the village and make a mask inspired by the spirit they encountered. They do not talk very much about the meaning of the dance. Where I lived with the North Baining ... they described the dances as play, an activity which carries many of the meanings it does for us: both an activity opposed to work, and a performance or spectacle. The dance is certainly a spectacle enjoyed not only by outsiders like us, but by the Baining themselves. (Fajans, 2007: online)

Fajans recalls how the fire dance was staged to suit the technical requirements of the film makers:

The crew didn't like where the fire was, nor did they like where the set up for the chorus was, so we rearranged it. The boys moved it back again, the crew moved it again, and finally everyone agreed that it was fine. Then, the fire was sort of kicked and shoved about 5-6 feet over, and that pleased everyone, too. (Fajans, 2007)

In an inversion of the encounter with the exotic Other, Fajans describes how the film makers themselves became the object of curiosity:

As the evening progressed, more and more Baining from the surrounding hamlets came into our hamlet to enjoy the dance and to watch the weird antics of the film crew. (ibid)

In this encounter at the 'far edges of the global', the 'global' is represented by the film maker's technologies and is apprehended as a set of values that contrast with those of local people's own cultural heritage, but may still be desirable for them to somehow to adopt. Anthropologist Rupert Stasch highlights the point that visited people often experience tourists as living, breathing personifications of metropolitan wealth, opportunities, and power. "Accordingly, they understand the social interactions between tourists and themselves to be concrete sites in which they forge interfaces with that social formation of metropolitan global modernity" (2014: 192).

Fictional spaces of representation are exemplified in adventure Hollywood films backed by James Cameron, such as Avatar, and more recently Sanctum, (Alister Grierson, 2011) for which Cameron was executive producer. The spectacular cave system featured in Sanctum is intended to be a representation of a Papua New Guinean landscape but was created from digitally enhanced cave footage in various locations including Mexico and Australia, with audio recordings from locally originated PNG material sourced from YouTube and modified to create the desired sounds. As Fitzgerald, Hayward and Brennan note: "In the 
sequence at the top of the cave, for example, the evocative birdcalls heard by audiences were actually produced by modifying sped-up recordings of dolphins and pigs" (2013: 113). Just as Deepsea Challenge utilises particular technologies to blur the lines between documentary representation and cinematic production, Sanctum utilises digital "planes of illusion" (ibid: 112) to create a particular adventurist fantasy of PNG and its interior cave spaces.

\title{
Tourism desires in the Nakanai Mountains
}

The Nakanai Range is a long way from the Rabaul-Kokopo tourism corridor. However, the transnational networks that interpolate the values of 'others' into the dynamics of cultural tourism in Rabaul are also informing desires to establish the Nakanai Mountains as a tourist destination. Landowners are creatively monetising their rugged environment in the hope of tapping into the lucrative opportunities that might be associated with the expansion of tourism in ENB. Tourist experiences anticipated include cave exploration, mountain climbing, bush trekking, game fishing, and 'cultural participation'. These activities fall broadly into the category of ecotourism, and more narrowly within the niche category of adventure tourism. Adventure tourism is situated within the broader category of so-called 'ACE tourism', which integrates adventure tourism, cultural tourism and ecotourism (Fennell, 1999; Fennell and Dowling, 2003; Ryan, 1998; Zurick, 1992).

\begin{abstract}
Adventure tourism can be defined by what it is not - mass tourism. Mass tourism includes large-ship leisure cruises, 'sun and sand' package vacations, bus tours around city centers that stop only at iconic attractions.... (UNWTO, 2014: 14)
\end{abstract}

Adventure tourists are willing to pay a premium for 'exciting' and 'authentic' experiences. Adventure tourists are described as "passionate about a certain sport or activity, tending to pursue the same activity trip after trip, seeking new and exciting destinations in the process" (UNWTO, 2014: 12). In the course of their adventures, remote tribal people are often turned into 'spectacles' for the tourist's camera, but from the viewpoint of villagers, tourists may be perceived as 'predatory voyeurs' (Hoskins, 2002).

Recent scholarship has investigated the relationship between the motivations of adventure tourists and the effects these types of activities have on local people in ecotourism destinations (Fletcher, 2014). Anthropological research suggests that adventure tourism provides a temporary escape from the tribulations of modern society by offering a transcendent 'wilderness' experience that contrasts with the indoor, sedentary life of mostly white-collar workers (Foale and Macintyre, 2005). The idea that one can go into the wilderness and achieve a kind of spiritual, transcendental experience was embraced by romantic transcendentalists in the nineteenth century, and encompassed in the idea of 'finding the sublime' in nature (Fletcher, 2014).

In his essay, A Philosophical Enquiry into the Origin of our Ideas of the Sublime and Beautiful, Burke (1757, cited in Sonntag, 2014) ( $^{5}$ explained that the terror of the sublime is an expression of awe and exultation rather than dread and loathing (Nash, 20o1). However, it was not until after the concept of 'wilderness' came to be associated with popular

${ }^{5}$ For Edmund Burke and Immanuel Kant, sublime landscapes included the mountaintop, canyon, thunderhead, chasm, waterfall, and rainbow (Sonntag, 2014: 25). 
destinations for romantic travellers that the 'wild' became less threatening, and the definitions of 'sublime' and 'beautiful' began to converge (Sonntag, 2014: 25).

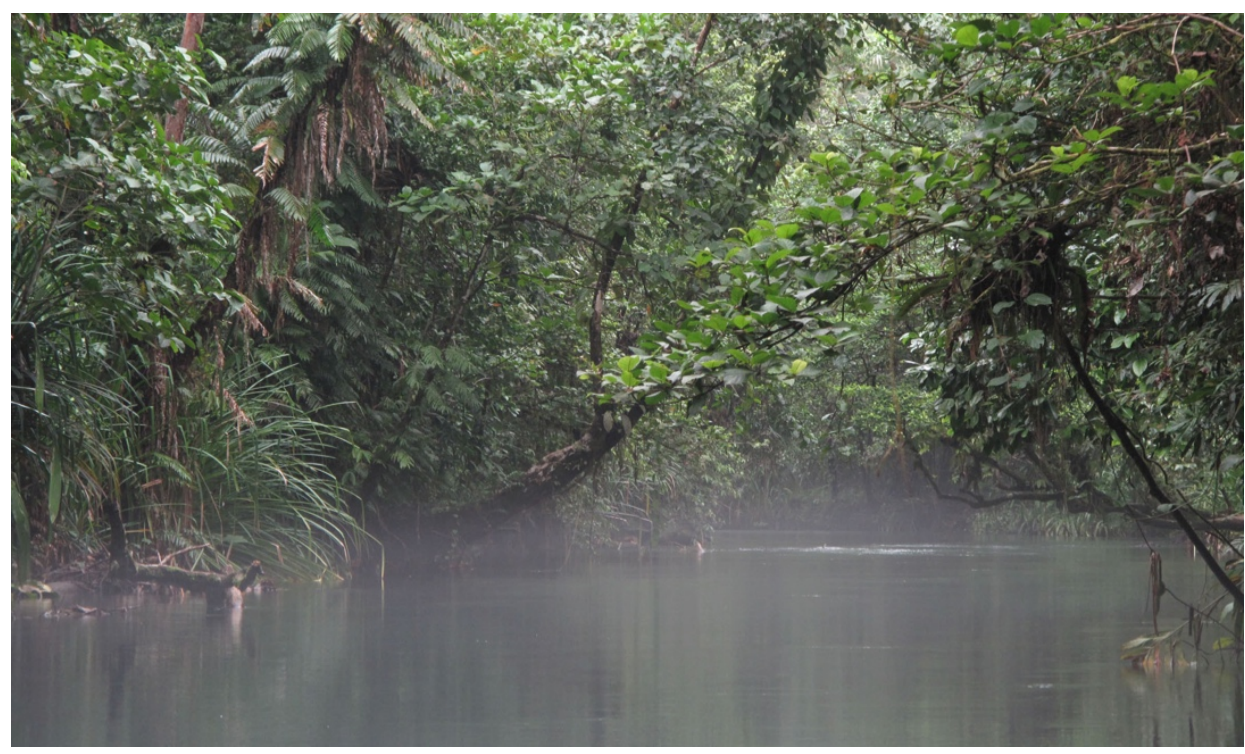

Figure 2 - The "sublime and beautiful" aesthetics of the Malop River mist (photograph: Foale 2015)

Despite the stunning aesthetics of pristine rivers and cascading waterfalls, tourist visitation to the Nakanai Range is restricted by accessibility and the cost of travel. The last leg of the journey to Jacquinot Bay involves a flight in a small plane from Kokopo, as well as the cost of hiring boats and guides to visit places of local significance along the coast. This, when added to the cost of air travel to get to PNG in the first place, and then across to the island of New Britain, has greatly restrained the tourist flow.

\section{The Sublime Karsts of PNG}

The Nakanai Range contains a globally unique system of limestone caves extending from the mountain summits to the southern coastline (Gill 2012, p.1). Since 1972, speleologists (cave explorers) have been mapping the caves and karst features, particularly the complex network of interconnected chambers and passages, including the underground drainage system of many of the caves and the relatively rapid rates of hydraulic water flow that wind through the giant cave systems before making their way out to sea (Audra and Maire, 2004). The Nare Cave, for instance, has a normal flow of 20-25 cubic metres per second, and an estimated flood flow of 1000 cubic metres per second (Maire, 1981; Gillieson, 1987: 511-2).

The mountains reach an altitude of 2185 metres in the north, and the slopes descending to the south coast are cut by canyons - such as those containing the Galowe, Wunung, and Bairaman rivers - that are more than 100 metres deep (Audra and Maire, 2004: 1152). The

\section{Shima Volume 11 Number 12017}

- 130 - 
continuous volume and turbulence of the underground rivers potentially makes them globally unique.

Deep beneath the rain forests of New Britain, an island off the coast of Papua New Guinea, churning rapids jet through enormous passages, some of the largest, most remote river caves on the planet. (Shea, 2006: online)

The deepest cave measured in the Nakanai Mountains is the one known as Muruk (meaning 'Cassowary' in Tok Pisin). This cave is 17 kilometres in length and 1178 metres in depth, and is the deepest cave known in the Southern Hemisphere (Richards and Gamui, 2011; Hache et al., 1995). Fetishism with the size of caves is an inherent part of caving exploration, but is not something that local people are generally concerned with.

The first caving expedition to the Nakanai Mountains was undertaken by an Australian team that explored the enormous Ora dolines (near Ora village) in 1972/3. In 1980, a French team undertook an initial exploration of the Nare River Cave, and the exploration of this cave was completed by a British team in 1984. Towards the end of their expedition, the British team took another look at the Ora dolines, and concluded that they warranted a further visit, but it was more than 20 years before this happened (Gill, 2012). A multinational team led by a British speleologist ${ }^{6}$ returned in 2006 on a two-month expedition named the 'Untamed Rivers Expedition', whose main purpose was to complete the exploration and mapping of the Ora River Cave and to search for other caves in the area. The secondary objective was to gather data with the aim of establishing a protected area that would be proposed for world heritage status in order to protect the area from destruction by logging. Funding was obtained from National Geographic magazine, whose editors sent along a photographic team and then published an article about the caves (Shea 2006).

Caves with a combined length of more than 12 kilometres were explored and mapped by this expedition. The first was the Ora River Cave upstream, which led to the discovery of the Little Ora River Cave. Upstream, the team discovered a 67-metre long, 58-metre wide lake which was named Lake Myo. Further upstream from the main river inlet was a 10metre high waterfall, named Myo Falls. On a helicopter flight into Ora village, a large and previously unrecorded cave entrance was seen emerging from high up on the cliff face to the south of the village. Entry into the cave required a 50-metre descent and a climb along the cliff to the waterfalls. Other caves documented include Mageni, a cave the team discovered by chance in the side of a gorge. Beyond the waterfall, Mageni opened onto more than 5 kilometres of cave tunnels, but the team only explored the main tunnel. Another small cave (61 metres long and 43 metres deep) was named Triosaurus.

To promote conservation of the caves, meetings were held in 2006 with the PNG Department of Environment and Conservation, the National Research Institute, the ENB Governor and Provincial Government, the TPA, LLG representatives from Pomio District, and non-governmental conservation organisations, as well local villagers. A presentation was then made to the World Heritage Secretariat in Port Moresby. As a result of the expedition, the Nakanai Mountains karst areas, together with two other karst areas on mainland PNG, were nominated by the PNG government to the UNESCO World Heritage

${ }^{6}$ The team consisted of 12 members: 7 from Britain, 4 from the USA, and 1 from France.

Shima Volume 11 Number 12017

- 131 - 
Bureau. The area was successfully inscribed on the World Heritage Tentative List as 'The Sublime Karsts of Papua New Guinea'.

This was a 'serial site' nomination that included the Muller Range and the Hindenburg Wall (both on the New Guinea mainland) as well as the Nakanai Mountains. The title of the nomination was chosen by Elery Hamilton-Smith, and reflects Edmund Burke's concept of the 'sublime' as an expression of otherworldly places: "Many karst systems are places of striking, even sublime beauty (Burke, 1756). In turn this is coupled, for many people, with a genuine sense of spirituality" (Hamilton-Smith, 2006). A capacious landscape that inspires awe and exultation, the Nakanai Range is as much the product of discursive and semiotic representations as a geological formation. Encompassing a karst area of more than 3000 square kilometres, the mountain range first came to international attention in the late 196os due to aerial photographs taken of immense dolines and shafts. The biological value of the region was highlighted by a 2009 expedition that uncovered more than 100 new species in 60 days (Richards and Gamui, 2011). While providing a glimpse of the rich biodiversity of the area, the findings reinforce the conventional Western "dualist image of nature as untouched, pristine and separate from (destructive) culture, and in need of protection from it" (Foale and Macintyre, 2005: 2).

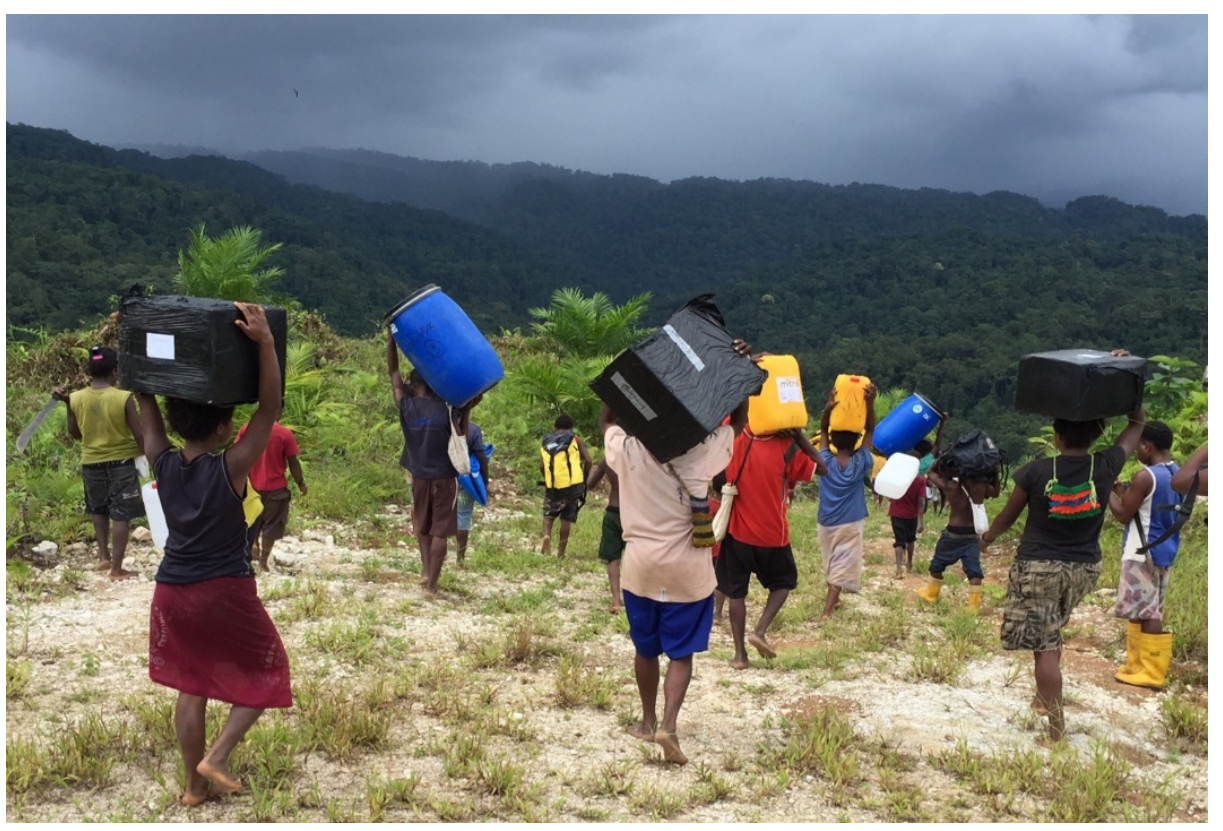

Figure 3 - Local porters carrying provisions for the Black Hole Caving Expedition Team, led by Jean-Paul Sounier (photograph: Gabriel, 2016).

Emerging tourism initiatives in the Nakanai Range draw upon narratives of the environment as "extreme terrain that presents a formidable challenge to explorers and researchers” (Richards and Gamui, 2011,). Karst landscapes, characterised by rivers,

${ }^{7}$ See http://whc.unesco.org/en/tentativelists/5064/

Shima Volume 11 Number 12017

$-132-$ 
limestone mountain peaks, gorges, massive caves, and giant sinkholes offer unique opportunities for adventure tourism. For extreme adventurers, the ruin of nature equates to the death of the sublime. Responding to the threat of mining, French speleologist JeanPaul Sounier lamented: "The Kavakuna-Galowe gorge is one of the most beautiful area[s] of the Nakanai (if mining starts, then of course I'll not be back)" (pc March 2016).

\section{Kayaking into 'otherworlds'}

The lure of adventure tourism in the Nakanai Range lies in conquering the ruggedness of the seemingly 'impenetrable' landscape, which in some accounts is represented as 'wilderness', depicting the total erasure of people. Although much of the rugged interior is sparsely populated, the Nakanai Range is also a cultural landscape that links cosmology to place, and place to people, through stories, walking tracks, and ancestral sites.

For extreme adventurers, the challenge of 'going where no man has gone', is congruent with narratives of discovery where 'empty' and 'pristine' environments are idealised sites, primarily for masculine self-fashioning. In an examination of surfing tourism in PNG, West (2014) highlights how those claiming to have discovered 'something' are editing out the people who live in that place and are thus disempowering them. Similarly, the fantasy of discovery in the Nakanai Range is attractive to extreme kayakers who seek new frontiers to conquer. Their narratives of discovery depict modernist representations of an idealised world encountered only by fictional characters or brave adventurers whose confrontation with danger is unparalleled.

Papua New Guinea's Beriman [Bairaman] Gorge is an otherworldly tropical paradise straight out of "Avatar": Twenty-five miles of turquoise river and billowy white falls carving through 4,0oo-foot sheer sandstone walls and unspoiled emerald jungle. Oh, and to date, it's utterly unnavigable and completely inescapable should something — anything - go wrong... So, what the heck? Let's give it a go. (Red Bull, 2015: online)

Collectively, extreme kayakers Ben Stookesbury, Chris Korbulic and Pedro Oliva have made nearly 200 first kayaking descents spread over six continents and 34 countries. They came together in the Nakanai Mountains in 2015 along with Ben Marr, hailed as the best kayaker in the world. Tagged 'the Grand Canyon of the South Pacific', the Bairaman Gorge descends 1524 metres as it cuts through the Nakanai Mountains. The water is neon blue from the minerals in the artesian groundwater that feeds the river. With cameras placed on the kayaks for the production of a Red Bull documentary, the kayakers began their journey. From a helicopter they descended into:

$20 \mathrm{~km}$ of unscoutable, never-descended whitewater hidden at the bottom of a gorge that rivals the size of the Grand Canyon, with soaring $300 \mathrm{~m}$ walls and pummelling rapids. To enter was an unquestionable risk of life - to exit was the achievement of a lifetime. (Red Bull, 2015: online)

Plunging through whitewater rapids, the team negotiated an 18-metre drop, as well as a 22-metre 'double drop' that they named Travartine Falls. The first gruelling 20 kilometres of enclosed canyons took twelve and a half days. The remaining 30 kilometres to the 
Solomon Sea was completed in just three hours. Describing their motivation, one of the kayakers explained:

To actually set foot in a place where no one else, not even the locals, have set foot before - it's an experience like no other. And I think that that's really one of the big reasons that keeps bringing us back to these places, that keeps us taking these really acute risks. It feels otherworldly. (Altschul, 2015: online)

The kayakers' representations speak to a desire to constantly seek out a liminal ('otherworldly') space where rites of passage involve transcending mundane, everyday life though extreme experiences. The experience is transcendental in that it is outside of normal time and even normal thought, for the subjects are wholly engaged with the intensity of activities that confronts them:

Just being beside the river changed my whole decision-making process. [It went] from this gorge that I'm just seeing photos of and trying to make a decision on how feasible the whole expedition sounds, to being at a river, which is the environment that I'm very comfortable in. And, at that point, I got way more excited about it, and ready to drop in and just start problem solving. (Altschul, 2015: online)

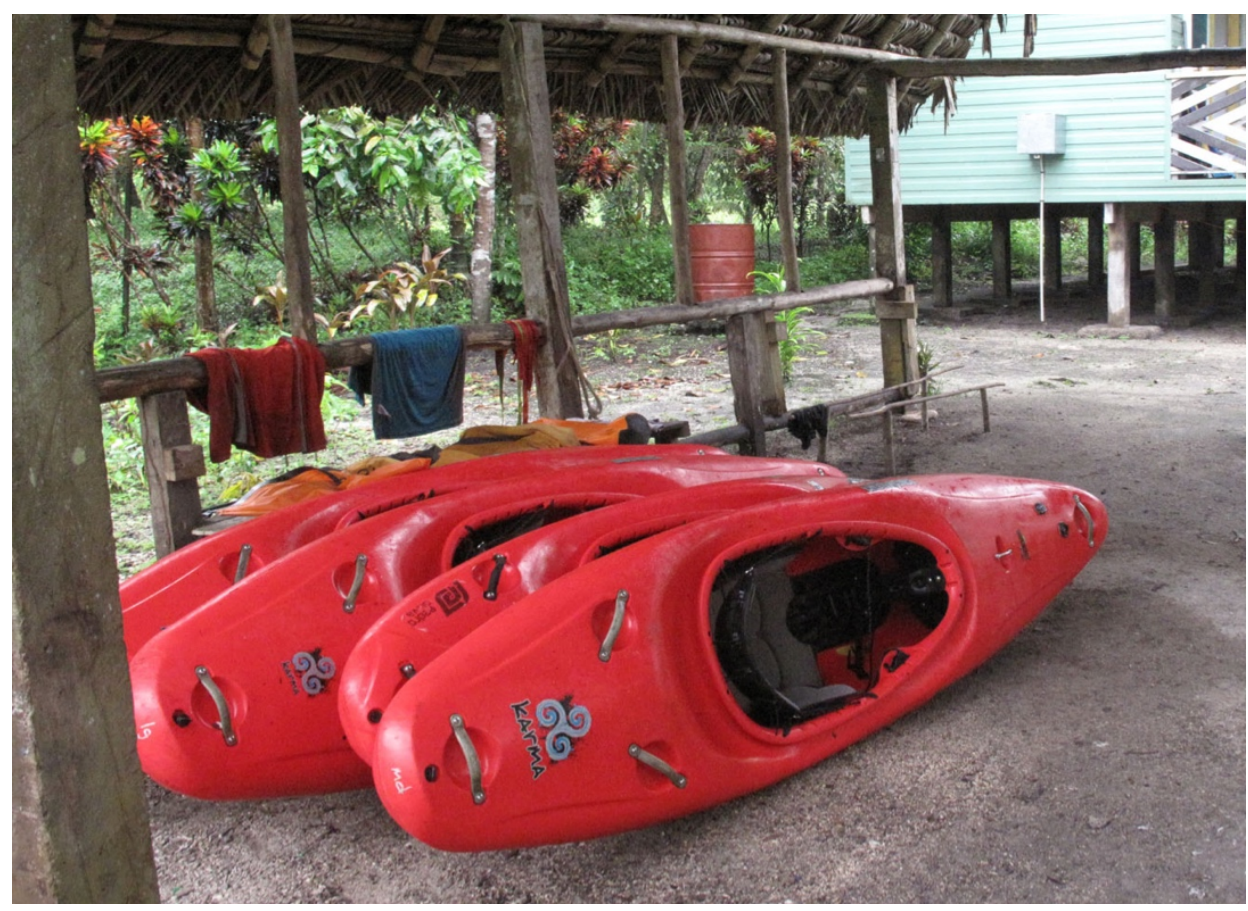

Figure 4 - Kyaks used in the Red Bull Documentary (photograph: Foale, 2015)

As Robert Fletcher's (2014) research into adventure tourism highlights, the ideal adventure occurs outside of ordinary life, is risky, unpredictable, and even dangerous at times. In adventure tourism, the confrontation involves elements of nature and elements of

\section{Shima Volume 11 Number 12017}


primarily white, upper middle class masculinity. The ideal adventure may also involve possible encounters with prehistoric dinosaurs, as elaborated by one of the Kayakers, Benn Marr:

The helicopter company that worked with the kayakers reported having taken other parties out to try to follow up on reported pterodactyl sightings. No one has captured footage of the creatures, but the kayakers agree that if pterodactyls still live on Earth, they would live in Papua New Guinea... If you came around the corner in the jungle and you saw a dinosaur, you would be like, "I guess that makes sense". (Altschul, 2015: online)

They did not encounter dinosaurs, but they did encounter animals that took on mythical proportions, according to kayaker Ben Stookesbury:

Tons of big gnarly-looking spiders, and giant fruit bats. the biggest bat on earth. They have wingspans of nearly $2 \mathrm{~m}$. The whole sky would be black with bats, just covered with their wings. Not attacking. Just flying. Every once in a while we'd get far enough away from the river, you'd hear tons of birds and other animals. But we were so close to this loud, rowdy river we didn't hear and see half of what's probably down there. (Red Bull, 2015: online)

\section{Seeking a pathway into tourism}

Service providers in the vicinity of the Nakanai Range include a small number of guesthouse and small-scale tourism operators, with limited resources for promotion and coordination. Landowners are keen to tap into opportunities for adventure tourism, and are actively pursuing an organisational framework. In order to promote tourism in the region, the local airstrip at Jacquinot Bay is being upgraded to enable the national carrier, Air Nuigini, to provide regular flights to the area through its subsidiary company, Link PNG (Unattributed, 2016b). For local community-based organisations such as the Jacquinot Bay Conservation and Ecotourism Association (JBCEA), adventure and cultural tourism, elusive as it seems, offers a far preferable alternative to industrial logging, oil palm development, or mining (Iggie Matapia, pers. comm., February 2016). JBCEA was formed by 11 representative members from the Central Inland Pomio and West Pomio Mamusi LLG areas. Their mandate is to identify and facilitate tourism sites for conservation within the Nakanai Range.

Linus Bai, a landowner from Pakia village, who operates primarily from Kokopo, is actively pursuing opportunities associated with the regional tourism marketing and tentative world heritage listing, and seeking the 'pathway to tourism' in Pomio. In his capacity as the owner of Nakanai Range Tours, Bai is working with other local landowners to formally establish the 'Trans New Britain Trail', which will enable tourists to trek from Jacquinot Bay to the north coast of the island. The trail involves a five-day walk through the rugged Nakanai Mountains, stopping along the way at mountain villages such as Pakia, which is only currently accessible on foot.

Small groups of trekkers (up to ten at a time) will walk past some of the mysterious caves and massive sinkholes the region is famous for, sleep in bush shelters, and end their journey at a sports fishing lodge in WNB. Porters will be engaged to assist tourists to trek 
overland. Local guides will be aware of special features and will explain to visitors the significance of caves, rivers, volcanoes and WWII sites along the way. Characteristically, adventure tourists do not mind the relative lack of comforts and infrastructure, as discomfort is an important part of their transcendental experience (Fletcher, 2014).

According to Linus Bai, who is now leading the push to have the land registered as a 'community conservation area':

Though there were serious questions raised but they stand to say yes. I salute my own clan elders for taking such decisions for the community benefit. There is likely to be 20,00o hectares to kickstart... I was appointed to spearhead the move as it will add more value to Trans New Britain Trail Track. In the meantime Nakanai MTS was [is] on the World Heritage Sites Tentative List but yet nothing is much done by UNDP (GEF) to address the issue. We are now moving forward to get everything running. We are now liasing with senior officers from CEPA to assist whenever we need help. (Linus Bai, Facebook post, 1 February 2016)

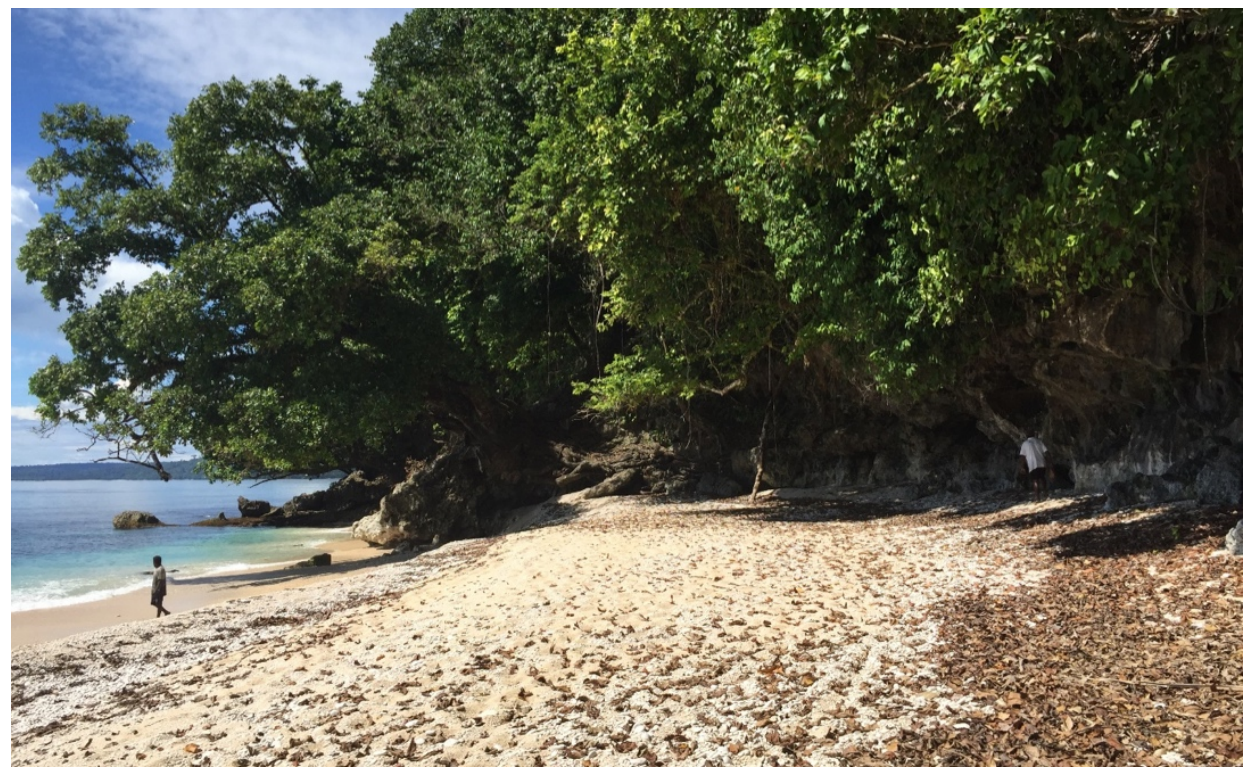

Figure 5 - Coastal beach along Jacquinot Bay (Image, Wood 2016)

Under the terms of the Protected Area Policy devised by PNG's Conservation and Environment Protection Authority (CEPA), ${ }^{8}$ which is yet to be endorsed by the National Executive Council, partnerships in protected area planning are expected to be supported by small grants from the United Nations Development Programme (UNDP). The UNDP office in Port Moresby is also responsible for implementing PNG's 'Community-Based Forest and Coastal Conservation and Resource Management Project', which has been funded by the Global Environment Facility (GEF) through its own partnership with CEPA. According to the GEF project document, at least 1,ooo,ooo hectares of new and additional

${ }^{8}$ Formerly the Department of Environment and Conservation.

Shima Volume 11 Number 12017

$-136-$ 
areas will be added to PNG's national system of community-managed protected areas. At least one such area is to be identified and established on the island of New Britain, and this could well include the proposed Nakanai World Heritage Area (GEF, 2011: 2). In a region lacking government infrastructure and utilities - including roads, bridges, electricity, water supplies and sanitation - the pursuit of tourism may be seen as an inversion of the search by 'outsiders' for an imaginary utopian realm.

Supplementing locally driven initiatives to lure tourists, social media forums are increasingly utilised by local actors to reproduce 'edenic' representations of place. Facebook sites such as 'Tourism in Pomio', 'Nakanai Range Tours', and 'Tourism in East New Britain' facilitate active participation in the reproduction of the Nakanai Range as an idealised landscape waiting to be experienced and conquered. Recent media reports (eg Bauai, 2016) announced that scouts from the international Survivor television 'reality' show are considering ENB as a suitable location to film three full series. This news generated an enthusiastic response on social media, with one observer issuing the challenge: "Show the Nakanai Ranges - we'll see how they survive above Muella" (Tourism East New Britain, Facebook post, 30 September 2016). ${ }^{9}$ The format of bringing ordinary or celebrity 'castaways' to a remote region and separating them into fictitious tribes to outwit, outplay and outlast one another, further reinforces the fantasy of 'otherworlds' waiting to be discovered by intrepid adventurers, and adds a further twist to the process or business of producing what Igoe (2010: 389 ) has called "images of spectacular nature".

Juxtaposed against the wilderness fantasies of unpeopled places encapsulated in sublime landscapes, and stereotyped in the Survivor series, images uploaded onto Facebook by landowners in Nakanai add a level of realism by re-embedding the unique qualities of the environment within a material and cultural (peopled) landscape. Through social media, local people actively participate in the spectacle of tourism by constructing their own representations of place, and in doing so affirm their identity, not only as landowners, but as thoroughly modern people. However, as Foale and Macintyre have argued, the use of idealised images to publicise ecotourism further

perpetuates a view of the Southwest Pacific as a site of Western consumption, excluding many of the harsh realities of life for local inhabitants and mystifying their relationship to, and understandings of their natural environment. (Foale and Macintyre, 2005: 2)

\section{Conclusion}

In contrast to the model of mass tourism developed in the Rabaul-Kokopo corridor, tourism initiatives in the Nakanai Range are primarily driven by landowners attempting to capture a niche market under the model of 'ACE tourism', with a specific focus on adventure travel through mountains, jungles, caves, and cascading rivers. Through their presence and repeated returns, cavers, kayakers and adventurers simultaneously produce and consume particular representations of places such as the Nakanai Range, which may be very different from local values.

${ }^{9}$ Muella is located in a remote inland mountainous area of Pomio District.

Shima Volume 11 Number 12017

$-137-$ 
Like the adventurers who seek personal insights and transcendental experiences, local actors live with a world of imagination about the benefits associated with tourism. Much like adventure tourism activities, flirting with the unknown impacts of tourism development is risky, unpredictable, and even dangerous at times. Too often, local people come to be treated as commodities or objects, or are displaced and dispossessed in the tourism encounter. As social scientists, we can immediately point to the problems posed by the imposition of tourism on local cultures, but tourism is often only one component in a larger, more complex cultural negotiation characterised by a high degree of contestation and local agency. Locally driven tourism initiatives do not necessarily desire encounters with people regarded as the walking embodiments of metropolitan wealth and global modernity, but may be seeking accessible channels to express their own visions of modernity, and to translate those visions into concrete actions. In such contexts, multiple, overlapping and contested representations of landscapes, defined by international imaginaries, industrial development, and local desires, can generate mechanisms for looking to other potentialities.

The danger of pursuing ecotourism as a conduit for change is that it often perpetuates Western fantasies of the environment as pristine, untouched, and unchanged, and risks subsuming the populations for whom the forests and reefs provide subsistence livelihoods into a future defined primarily by outsiders. Privileging landscape or biodiversity values over local livelihoods is not a panacea against poverty, and may even exacerbate structural inequalities. In the embryonic stage of tourism development discussed in this paper, the broad range of impacts at the local level are yet to be seen. But in the socio-temporal space in which they occur, the semiotic relationships between the wider world and the sociocultural world provide a way for people to imagine self-made transformations. In this land of grumbling volcanoes, the value of ecotourism will depend upon levels of local agency and ownership, including the ability to retain control over resources, and the capacity to prevent tourist fantasies from radically impacting upon traditional livelihoods and cultural landscapes.

\section{BIBLIOGRAPHY}

Allen, B (2015) 'Papua New Guinea: indigenous migrations in the recent past' in Ness, I and Bellwood, P (eds) The Global Prehistory of Human Migration, Chichester: Wiley-Blackwell: 302-307

Altschul, J (2015) 'Exploratory Kayakers Ben Stookesberry, Benny Marr, Chris Korbulic, Pedro Oliva', National Geographic, November:

http://www.nationalgeographic.com/adventure/adventurers-of-the-

year/2016/stookesberry-marr-korbulic-oliva/ - accessed January 3oth 2017

Aplin, K.P and Opiang, M (2011) 'The mammal fauna of the Nakanai Mountains, East New Britain Province, Papua New Guinea' in Richards, S.J and Gamui, B.G (eds) Rapid Biological Assessments of the Nakanai Mountains and the Upper Strickland Basin: Surveying the Biodiversity of Papua New Guinea's Sublime Karst Environments, Arlington: Conservation International (RAP Bulletin n6o): 85-103

Audra, P and Maire, R (2004) 'Nakanai Caves, Papua New Guinea', in Gunn, J (ed) Encyclopaedia of Caves and Karst Science, New York: Fitzroy Dearborn: 1150-1154

Shima Volume 11 Number 12017

$-138-$ 
Bauai, G (2016) 'Survivor reality show scouts describe Kokopo as "perfect", PNG Loop: http://www.looppng.com/content/survivor-reality-show-scouts-describe-kokopo\%E2\%8o\%98perfect $\% \mathrm{E}_{2} \% 80 \% 99$ - accessed January 3oth 2017

Buchanan, G.M, Butchart, S.H.M, Dutson, G, Pilgrim, J.D, Steininger, M.K, Bishop K.D and Mayaux, P (2008) 'Using remote sensing to inform conservation status assessment: estimates of recent deforestation rates on New Britain and the impacts upon endemic birds', Biological Conservation v141 nı: 56-66

Coronado, G (2014) 'Selling culture?: between commoditisation and cultural control in Indigenous alternative tourism', PASOS: Journal of Tourism and Cultural Heritage v12 n1: 1128

Cramb, R and Curry, G.N (2012) 'Oil palm and rural livelihoods in the Asia-Pacific region: an overview', Asia Pacific Viewpoint v53 n3: 223-239

Davies, H (1995) 'The 1994 eruption of Rabaul volcano: a case study in disaster management', report to UN Development Programme office, Port Moresby: http://www.pacificdisaster.net/pdnadmin/data/original/JB_DM311_PNG_1994_disaster_ma nagement.pdf - accessed January 3oth 2017

Duncanson, W (2002) 'Transformation in the traditional Himalayan landscape: the rise of the trekking hotel in Nepal', Traditional Dwellings and Settlements Review v13 n2: 7-21

Epstein, T.S (1968) Capitalism, Primitive and Modern: Aspects of Tolai Economic Development, Canberra: Australian National University Press

Fajans, J (1997) They Make Themselves: Work and Play among the Baining of Papua New Guinea, Chicago: University of Chicago Press

Fajans, J (2012) 'Papua New Guinea blog 5: fire dance', National Geographic Education Blog: http://blog.education.nationalgeographic.com/2012/o4/17/papua_new_guinea_blog_5/ _ accessed January 3oth 2017

Fennell, D.A (1999) Ecotourism: An Introduction, London: Routledge

Fennell, D.A and Dowling, R.K (eds) (2003) Ecotourism Policy and Planning, New York: CABI Publishing

Filer, C (1997) 'A statistical profile of Papua New Guinea's log export industry' in Filer, C (ed) The Political Economy of Forest Management in Papua New Guinea, Port Moresby: National Research Institute (Monograph n32): 207-248

Filer, C and Lowe, M (2011) 'One hundred years of land reform on the gazelle peninsula: a Baining point of view' in Strang, V and Busse, M (eds) Ownership and Appropriation, Oxford and New York: Berg

Fitzgerald, J, Hayward, P, and Brennan, D (2013) 'Planes of illusion: music soundtrack, rendition and attribution in Sanctum', Perfect Beat v13 n2: 111-126 
Fletcher, R (2014) Romancing the Wild: Cultural Dimensions of Ecotourism, Durham: Duke University Press

Foale, S. and Macintyre, M (2005) 'Green fantasies: photographic representations of biodiversity and ecotourism in the Western Pacific', Journal of Political Ecology v13: 1-21

Gabriel, J, Nelson, P.N, Filer, C, and Wood, M (forthcoming 2017) 'Oil palm development and large-scale land acquisitions in Papua New Guinea' in McDonnell, S, Allen, M.G and Filer, C (eds) Kastom, Property, and Ideology: Land Transformations in Melanesia, Canberra: Australian National University Press

Gartner, W (2004) 'Rural tourism development in the USA', International Journal of Tourism Research v6 n3: 151-164

GEF (Global Environment Facility) (2011) 'PAS community-based forest and coastal conservation and resource management in PNG', unpublished project document

Gill, D (2012) 'Untamed Rivers of New Britain Expedition 2006: Nakanai Mountains, East New Britain, Papua New Guinea', Report on the 2006 British Caving Expedition to New Britain, Papua New Guinea: http://daveclucas.com/cms/index.php/expeditions/newbritain/15-untamed-rivers-of-new-britain-expedition-report-the-

expedition?showall=1\&limitstart $=$ - accessed January 3oth 2017

Gillieson, D (1987) 'Tropical caves in retrospect and prospect', Progress in Physical Geography v11 n4: 511-532

Global Witness (2014) 'The people and forests of Papua New Guinea under threat: the government's failed response to the largest land grab in modern history', London: Global Witness November

Hache, P, Hoblea, F, Philips, M, Sessegolo, D and Sounier, J.-P (1995) 'Muruk, hemisphere sud, premier - 1000', Spelunca n6o: 35-54

Hamilton-Smith, E (2006) 'Spatial planning and protection measures for karst areas', Acta Carsologica v35 n2: 5-11

Hanson, L.W, Allen, B.J, Bourke, R.M, and McCarthy, T.J (2001) Papua New Guinea Rural Development Handbook, Canberra: The Australian National University, Research School of Pacific and Asian Studies

Honey, M (1999) Ecotourism and Sustainable Development: Who Owns Paradise?, Washington: Island Press

Honey, M (2008) Ecotourism and Sustainable Development: Who Owns Paradise?, Washington: Island Press ( $2^{\text {nd }}$ edition)

Hoskins, J (2002) 'Predatory voyeurs: tourists and "tribal violence" in remote Indonesia', American Ethnologist v29 n4: 797-828 
Igoe, J (2010) 'The spectacle of nature in the global economy of appearances: anthropological engagements with the spectacular mediations of transnational conservation', Critique of Anthropology v30 n4: 375-397

International Ecotourism Society (nd) 'What is Ecotourism?', http://www.ecotourism.org/what-is-ecotourism - accessed January 3oth 2017

Jędrusik, M (2004) 'Nature and tourism on tropical and subtropical islands', Miscellanea Geographica v11: 271-28o

Lattas, A (2010) Dreams, Madness and Fairy Tales in New Britain, Durham: Carolina Academic Press

Lindemalm, F. and Rogers, H.M (2001) 'Impacts of conventional logging and portable sawmill logging operations on tree diversity in East New Britain, Papua New Guinea', Australian Forestry v64 n1: 26-31

Maire, R (1981) 'Giant shafts and underground rivers of the Nakanai Mountains (New Britain in Papua New Guinea)', Spelunca n3: 8-29

Martin, K (2013) The Death of the Big Men and the Rise of the Big Shots: Custom and Conflict in East New Britain, New York: Berghahn Books

Mayring, S (2015) 'Changing times in Papua New Guinea', Travel Weekly, September 17th: http://www.travelweekly.com/Asia-Travel/Changing-times-in-Papua-New-Guinea accessed February 26th 2017

McGavin, K (2007) 'Tourism, Gender and Ethnicity in West New Britain', (unpublished) $\mathrm{PhD}$ thesis, University of Queensland, School of Social Science

Nash, R.F (2001) Wilderness and the American Mind, New Haven: Yale University Press

Nelson, P.N, Gabriel, J, Filer, C, Banabas, M, Sayer, J.A, Curry, G.N, Koczberski, G and Venter, O (2014) 'Oil palm and deforestation in Papua New Guinea', Conservation Letters v7 n3: 188-195

Nepal, S.K (2007) 'Tourism and rural settlements: Nepal's Annapurna tegion', Annals of Tourism Research v34 n4: 855-875

Neumann, K (1996) Rabaul Yu Swit Moa Yet: Surviving the 1994 Volcanic Eruption, Melbourne: Oxford University Press

Oxford Business Group (2015) The report: Papua New Guinea 2015, London: Oxford Business Group

Nielsen, N.R, and Wilson, E (2012) 'From invisible to Indigenous-driven: a critical typology of research in Indigenous tourism', Journal of Hospitality and Tourism Management v9 n1: $67-75$ 
Panoff, M (1969) Inter-Tribal Relations of the Maenge People of New Britain, Canberra: Australian National University, Research School of Pacific Studies, New Guinea Research Unit (Bulletin nzo)

P\&O Destinations (n.d.) 'Rabaul, Papua New Guinea', https://www.pocruises.com.au/destinations/papua-new-guinea/papua-newguinea/rabaul- — accessed January 3oth 2017

PNGTA (PNG Trekking Adventures) (nd) 'Rabaul Mask Festival', http://www.pngtrekkingadventures.com/detail/rabaul_mask_festival_- accessed January 10th 2017

PNGTPA (PNG Tourism Promotion Authority) (nd) 'East New Britain Province', http://www.papuanewguinea.travel/eastnewbritain — accessed January 3oth 2017

Red Bull (2015) 'Explore the Grand Canyon of the South Pacific', http://www.redbull.com/au/en/adventure/stories/1331758996913/this-crazy-kayak-tripwon-a-nat-geo-aoty-award- - accessed January zoth 2017

Rew, A (1993) 'States of anxiety: cultural identities and development management in East New Britain' in Campbell, J.R and Rew, A (eds) Identity and Affect: Experiences of Identity in a Globalising World, London: Pluto Press: 130-166

Richards, S.J and Gamui, B.G (eds) (2011) Rapid Biological Assessments of the Nakanai Mountains and the Upper Strickland Basin: Surveying the Biodiversity of Papua New Guinea's Sublime Karst Environments, Arlington: Conservation International (RAP Bulletin n6o)

Robertson, R (1992) Globalisation: Social Theory and Global Culture, London: Sage

Rohatynskyj, M.A (2001) 'On knowing the Baining and other minor ethnic groups of East New Britain', Social Analysis v45 n2: 23-40

Russo, A.P (2006) 'A re-foundation of the TACL for Heritage Cities' in Butler R.W (ed) The Tourism Area Life Cycle Vol. 1: Applications and Modifications, Bristol: Channel View Publications: 139-180

Ryan, C (1998) 'Dolphins, canoes and marae: ecotourism products in New Zealand' in Laws, E, Faulkner, B and Moscardo, G (eds) Embracing and Managing Change in Tourism: International case studies, London: Routledge: 285-306

Saarinen, J (2004) 'Destinations in change: the transformation process of tourist destinations', Tourist Studies v4 n2: 161-179

Sakata, H, and Prideaux, B (2013) 'An alternative approach to community based ecotourism: a bottom-up locally initiated non-monetised project in Papua New Guinea', Journal of Sustainable Tourism v21 n6: 880-899

Salisbury, R.F (1969) Vunamami: Economic Transformation in a Traditional Society, Berkeley: University of California Press 
Shackley, M (1998) Visitor Management: Case Studies from World Heritage Sites, Oxford: Butterworth-Heinemann

Shea, N (2006) 'Raging danger', National Geographic, September: http://ngm.nationalgeographic.com/2006/o9/raging-danger/shea-text - accessed January 3oth 2017

Sonntag, K.E (2014) 'The role of the transcendent in landscapes', (unpublished) Masters thesis, Utah State University, Department of Landscape Architecture and Environmental Planning

Stasch, R (2014) 'Primitivist tourism and romantic individualism: on the values in exotic stereotypy about cultural others', Anthropological Theory v14 n3: 191-214

Tateyama, H (2006) 'Tubuan: History, Tradition, and Identity among the Tolai of Papua New Guinea', (unpublished) PhD thesis, University of British Columbia, Department of Anthropology

Tourism East New Britain (nd) Facebook page: https://www.facebook.com/groups/884220748317043/ - accessed 26th February 2017

Threlfall, N (2012) Mangroves, Coconuts and Frangipani, Rabaul: Rabaul Historical Society UNWTO (World Tourism Organisation) (2014) Global Report on Adventure Tourism, Madrid: UNWTO

Unattributed (2016a) 'East New Britain to host 1000 tourists from cruise ship Pacific Aria', PNG Today: http://news.pngfacts.com/2016/o2/east-new-britain-to-host-1oootourists.html - 13 January 13th 2017

Unattributed (2016b) 'Work on airstrip to start soon', The National, December 7th: http://www.thenational.com.pg/work-airstrip-start-soon/ - accessed January 3oth 2017

Wang, N (200o) Tourism and Modernity, Amsterdam: Pergamon

West, P (2014) "Such a site for play, this edge": surfing, tourism and modernist fantasy in Papua New Guinea', The Contemporary Pacific v26 n2: 411-432

Whitehouse, H (1990) 'A cyclical model of structural transformation among the Mali Baining', Cambridge Journal of Anthropology v14 n3: 34-53

Wilson, M, Ballard, C and Kalotiti, D (2011) 'Chief Roi Mata's domain: challenges for a world heritage property in Vanuatu', Historic Environment v23 n2: 5-11

Wood, R (2000) 'Caribbean cruise tourism: globalisation at sea', Annals of Tourism Research v27 n2: 345-70

Zurick, D (1992) 'Adventure travel and sustainable tourism in the peripheral economy of Nepal', Annals of the Association of American Geographers v82 n4: 6o8-28 